表 1 各種レーザー光の特性

\begin{tabular}{|c|c|c|c|}
\hline & $\mathrm{CO}_{2}$ & KTP & Nd-YAG \\
\hline 媒質 & $\mathrm{CO}_{2}$ (気体) & $\mathrm{Nd}-\mathrm{YAG} \rightarrow \mathrm{KTP}$ & Nd-YAG \\
\hline 波 & $10,600 \mathrm{~nm}$ & $532 \mathrm{~nm}$ & $1,064 \mathrm{~nm}$ \\
\hline 吸 & $\mathrm{H}_{2} \mathrm{O}$ & 赤色色素 & 不良 \\
\hline 散乱 & 少 & 中間 & 多 \\
\hline $\begin{array}{l}\text { 周 囲 } \\
\text { 組織障害 }\end{array}$ & 表層 & 中間 & 深層 \\
\hline 導 光 & 多関節ミラー & 石英ファイバー & 石英ファイバー \\
\hline
\end{tabular}

表 $2 \mathrm{CO}_{2}, \mathrm{KTP}$ 両レーザーの臨床的比較

\begin{tabular}{c|l|c|c}
\hline \hline & & $\mathrm{CO}_{2}$ & $\mathrm{KTP}$ \\
\hline 術 中 & ハンドピースの & やや不良 & 良 \\
& 甲介作性 & & \\
& 甲介後端の処理 & 難 & 易 \\
& 出力減哀 & 多 & 少 \\
術 後 & oozing & なし〜少 & 少 \\
& 上皮化 & $4 \sim 6$ 週 & $8 \sim 10$ 週 \\
コスト & & 低 & 高
\end{tabular}

ンドピースがやや太く非接触照射となるので，鼻内での 操作性が劣り，下鼻甲介手術で特に問題となる後端の処 理に難点が残る。また先端出力の減衰も，特に側射型八 ンドピースに损いては, 先端の反射鏡が炭化した組織片 や凝血塊で污染されると顕著なものとなる。一方， KTP/532 レーザーでは，ハンドピースも細径で接触抒 よび非接触照射が可能であるゆ元に，鼻内での操作性は 良好で下鼻甲介後端も十分に処理することができる．先 端出力の減衰も $\mathrm{CO}_{2}$ レーザーに比べ軽微である。しか
しながら, 術後の鼻粘膜創傷治瘉に関しては, $\mathrm{CO}_{2}$ レー ザーでは $4 \sim 6$ 週間, KTP/532 レーザーでは $8 \sim 10$ 週 間を要し， $\mathrm{CO}_{2}$ レーザーに比べ $\mathrm{KTP} / 532$ レーザーでは $2 \sim 6$ 週間治癒が遷延する傾向にあった.

下鼻甲介粘膜を蒸散する場合も切除する場合も，その 目的は, アレルギー反応の場である鼻粘膜を十分に減量 せしめ, レーザーの持つ熱作用により鼻粘膜を凝固变性 させることにある。その意味においては， $\mathrm{CO}_{2}, \mathrm{KTP} /$ 532 いずれのレーザーもその目的を達し得るが, 後者の 方が，より確実に十分量の鼻粘膜を処置することができ， それが治療成績に反映したものと考える。

\section{参考文献}

1) Lenz H : Acht Jahre Laserchirurgie an den unteren Nasenmuscheln bei Rhinopathia vasomotorica in Form der Laserstrichkarbonisation. HNO $33: 422 \sim 425,1985$.

2 ）福武知重, 山下敏夫, 友田幸一, 他 : 鼻アレルギーに対す るレーザー手術. 耳鼻臨床 $81: 1163 \sim 1179,1988$.

3 ) Elwany S and Harrison R : Inferior turbinectomy ; comparison of four techniques. J Laryngol Otol $104: 206 \sim 209$, 1990.

4) Levine HL : The potassium-titanyl phosphate laser for treatment of turbinate dysfunction. Otolaryngol Head Neck Surg $104: 247 \sim 251,1991$.

5 ) 窪田市世 : 鼻アレルギーに対する下甲介レーザー手術. JOHNS $10: 375 \sim 381,1994$.

6 ）古田 茂, 出口浩二, 大山 勝: 鼻アレルギーに対する物 理療法. JOHNS $10: 389 \sim 392,1994$.

7 ) 中之坊学 : 鼻アレルギーのレーザー手術に関する研究. 耳 鼻臨床 補77 : 1 21, 1995.

\title{
3. 鼻過敏症に対するレーザー治療
}

\section{久保 伸夫 ·川村 繁樹・福武 知重 - 山下 敏夫}

\section{はじめに}

通年性アレルギー性鼻炎症例に対して, 各種抗アレル ギー薬投与, 抗原の除去, 減感作療法などが行われてい るが，膨大な患者の内にはこれらの治療に抵抗する症例
も多く，時間的経済的負担から長期間の治療にドロップ アウトする症例も多い。また下甲介切除などの手術療法 も行われているが，最大の患者層である若年者には疼痛 や出血から困難な場合も多い。我々は, このよらな保存 
的治療の効果の得られなかった症例に対する下甲介粘膜 $\mathrm{CO}_{2}$ レーザー照射術を1983年邦文で1)，1986年英文で2), いずれも初めて報告し，以来約1500症例に対し，ほぼ同 一のプロトコールで本法を行い，これまでに長期成績や 作用機序に関する検討を報告している31 8). 本稿ではそ れらの結果をまとめ,さらに近年我々が行っている内視 鏡下鼻内レーザー蝶口蓋神経神経切断術 (黄川田一増田 法)の手術法と術後成績をあわせ報告する.

\section{$\mathrm{CO}_{2}$ レーザーによる下鼻甲介粘膜蒸散術}

\section{対象と方法}

対象患者：対象となったのは, くしゃみ, 水様性鼻汁, 鼻閉を主訴とし，CAP RAST あるいは抗原誘発テスト によって，ダニあるいは八ウスダストによる通年性鼻ア レルギーと診断され, 各種保存的治療に 2 年間以上抵抗 した症例であり，1983年から1987年の間には 5 歳から 79 歳の男女約 1300 名である. このらち今回長期成績の評価 対象となるのは, 術後 1 力月まで他の治療を受けず, 経 過を観察できた 365 例，初回照射以降他の治療を受けず， 2 年以上経過を打えた 45 例, 初回治療以降再診せず， ア ンケートによって症状を把握した22例である.

レーザー装置と手術手技: 当科外来に専用レーザー装 置を設置した.1982年から1989年は日本赤外線社製レー ザー60炭酸ガスレーザーメスに, 独自に開発した鼻腔内 照射用ハンドピース(正面照射用拉よび側方照射用)を用 いて行った。この装置は約1200症例のべ6000回照射した 時点で，修理不能となり，1990年に同社製レーザーIR 101 炭酸ガスレーザーメスに更新し，現在は持田製薬製 メディレーザー $30 \mathrm{~S}$ とあわせて用いている. 実際のレー ザー手術は $4 \%$ リドカインと当量の 1000 倍希釈エピネフ リンを浸したガーゼを15分間固有鼻腔に挿入し，表面麻 酔を行った後，下鼻甲介粘膜をできるだけ広範囲に15～ 18 ワトの defocused beamを0.1秒の断続照射で約 1 分間かけ両側に照射する. この照射を週 1 回連続 5 週間 行っている. この方法では初回困難な下鼻甲介後端の照 射も5 回目の照射では容易に行える.

\section{結果と考察}

重症度扣よび自覚症状の改善度 : 中等度以上の重症度 をしめした症例は術前 $92 \%$, 術後 1 力月で $17 \%$, 術後 2 年で30\%であった5)。著明改善と中等度改善をあわせた
自覚症状の改善度は，術後 1 力月で $78 \% ， 2$ 年後 $76 \%$, 3 年後 $75 \%$ であり, 短気的に有効であった症例の効果は 持続する傾向をしめした5)6). 但し, 術後 1 カ月では, $53 \%$ にみられた著明改善が， 2 年後には $36 \%$ に減少し，他の 症例では中等度改善に効果は低下していた6)。また，ア ンケートによる評価でも 1 カ月後の有効率は 22 例中17例, $77 \%$ であり，そのうち， 3 年後に症状の悪化を及とめた のは，4 例のみであった6).

症状別改善度 : 術後 1 力月の時点での改善率は, くしゃ み $77 \%$ ，鼻汁 $75 \%$ ，鼻閉72\%であった6)。2 年後では， 各症状ともほぼ同率に 6 ～8\%低下していた6).

年齢別改善度 : 術後 1 力月の重症度の改善率は, 12 歳

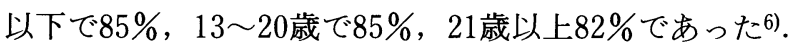
一方， 2 年後では， 12 歳以下 $88 \% ， 13 \sim 20$ 歳 $77 \% ， 21$ 歳 以上 $76 \%$ であった6)。ともに，若年者の方が，改善率は 高かった．他の手術治療の困難な小児により有効である といら点は本法の大きな特徵といえる.

再照射の有効性 : レーザー照射後, 症状の再発により, 再照射を行い 2 年間以上再照射後の経過を観察した 27 症 例に関する検討では，再手術の有効性は 1 力月後 $85 \%$ ， 2 年後 $78 \% ， 3$ 年後 $64 \%$ であった7)。さらに，これらを 初回手術後 1 年未満で再発した早期再発群 7 例と 1 年以 上たってから再発した晚期再発群20例に分けて検討する と, 晚期再発群の方が，短気的にも，長期的にも，高い 有効率をしめした7)。つまり，1 年以内に再発した症例 には再照射を行ってもレーザー治療だけで鼻症状の長期 管理は難しいが， 1 年以上たって再発した症例では，年 に 1 回程度の再照射で長期管理が可能であることをしめ している.

鼻腔通気度 : 抗原誘発前後の鼻腔抵抗值の変化をレー ザー治療前後で比較すると, 誘発前の抵抗值には治療前 後での変化は見られなかった8).しかし，誘発後の鼻腔 抵抗值は，治療後有意に低下していた8)。さらに，誘発 による変化率は，治療前では72\%の抵抗の増大がみられ たのに対し，治療後では16\%しか抗原誘発に反応せず， 有意な変化であった8)。すなわち，本法は下鼻甲介粘膜 を減量させる粘膜切除術の効果はなく，抗原刺激に対す る粘膜の過敏性を低下させる効果が主な作用機序と考兄 られた. 以上の理由から, 我々は本法を鼻アレルギーに 対する minimally invated functional surgery と位置づけ ている.

鼻粘膜血流量 : レーザードップラー法により, 抗原誘 
発前後の鼻粘膜表層の血流量の変化をレーザー治療前後 で比較すると, 鼻アレルギー患者では正常者に比べて有 意に低下している血流量は，レーザー治療によりさらに 低下した8)。また治療前, 誘発により有意に増加してい た血流量は, 治療後, 誘発に対し有意な変化を示さなく なった．従って，血流動態の点からは本法は生理的な治 癒機転をとらないといえる.

鼻腔洗浄液中 $\mathrm{ECP}$ 量 : 抗原誘発後の鼻腔洗浄液中の ECP (eosinophil cationic protein)の定量では, 治療前 $121.1 \pm 16.1 \mathrm{ng}$ に対し, 治療後は $57.2 \pm 11.1 \mathrm{ng}$ まで 有意に低下した8)。また, 症状改善群と非改善群の間で は ECP の変化率に有意差がみられた。

組織学的研究：治療後 2 力月の下甲介粘膜では, レー ザ一照射直後は消失していた粘膜上皮は注ぼ再生され， 一部に扁平上皮化成を伴い，杯細胞は著明に減少してい た6).また粘膜下固有層の表層は広い範囲で血管の乏し い撚痕組織で置換されていた。術後 5 年を経過した標本 に执いても，これらの扁平上皮化成や杯細胞減少，㗪痕 組織形成はなおみとめられ，上皮下浮腫や炎症細胞浸潤 はみられなかった6).

以上の結果から，鼻アレルギーに対するレーザー下甲 介照射術は，術後 2 年以上の長期成績でも，短期成績と 同程度の $76 \%$ の有効率を示し, 再発した症例に対しても， $70 \%$ で再照射が有効であり，特に再発までの有効期間の 長かった症例では効果的であった。 このことは, 年 1 回 程度の照射により，85\%以上の患者で鼻過敏症状を制御 できることをしめして拉り, 本法はわずかな時間的経済 的負担で，長期的な管理が可能な治療法とい兄る。 また， 他の手術治療の困難な若年群でより有効という結果は, 本法の大きな特徵といえる.さらにその作用機序は, レー ザー照射によりアレルギー反応の場である鼻粘膜表層に， 瘢痕組織が生成され，長期間吸収されない点にあると考 えられた。このように，本法は，単なる局所療法に過ぎ ず，减感作療法などの上らな原因治療は期待できないが， 症状の制御といら点からは，極めてわずかな時間的経済 的負担で, 長期的な管理が可能で，特に若年者には有効 な治療法といえる。

\section{内視鏡下鼻内レーザー蝶口蓋神経切断術}

\section{（黄川田一増田法）}

鼻腺の分泌は，大錐体神経由来副交感神経瀻維を含む 翼突管神経 (ヴィディアン神経)に支配され，同神経の切
断で鼻アレルギーに伴ら鼻汁分泌の $80 \%$ は抑制されると 報告されている。しかし，本手術は，技術的に難しい点 (特に鼻内法は視野の確保が困難), 再発が多い点, さら に翼口蓋神経節より中枢側で切断するため淚腺分泌神経 が儀牲になりドライ・アイをきたす点など，問題が多く 近年かえりみられていなかった．黄川田らは，内視鏡を 用いることで，技術的に困難であった鼻内からの蝶口蓋 孔へのアプローチが可能となることをしめし，蝶口蓋孔 周囲粘膜へのレーザー照射によって鼻粘膜に分布するヴ ィディアン神経鼻枝の切断を行う内視鏡下鼻内レーザー 蝶口蓋神経切断術を行っている9 . 本法は涙腺神経分岐 部より末梢で処理するためドライ・アイなどの副作用が みられず，手術侵襲が少ない点で優れているが，技術的 には蝶口蓋孔同定と蝶口蓋動脈への損傷の回避が注意点 となる。

\section{対象と方法}

我々は下鼻甲介レーザー手術無効例やこれまでヴィデ イアン神経切断術の対象となっていた遠心性鼻過敏症 (血管運動性鼻炎)症例を対象に本法を施行し，1993年12 月より1995年 1 月までに行い少なくとも 6 力月間術後経 過を追えた14例25側に関して術後成績と合併症を検討し た. 蝶口蓋孔は中鼻甲介後端の鼻腔側壁への付着部の後 方に位置するが，その同定が本法の最も重要な点である。 黄川田氏は先端直径 $3 \mathrm{~mm}$ の $\mathrm{A}$ モードェュープローブを 用いて同定している．増田氏は上頡神経ブロックと同様 の方法でインディゴカルミンを注入し翼口蓋窩を染色し 鼻内から同定している. 我々は口内から経大口蓋孔経由 で翼口蓋窩にいたり同所を染色する方法をとっている. 同定された翼口蓋孔を中心に $\mathrm{CO}_{2}$ ，接触型 $\mathrm{YAG}$ あるい はKTP レーザーを用いて，粘膜表面を蒸散させる。そ の際, 蝶口蓋動脈の損傷を避けるために, 蝶口蓋孔中心 より周囲を深く蒸散させ，さらに下鼻甲介後端部の粘膜 にも照射する.

\section{結果と考察}

術後合併症は, 術後出血 2 例, 一過性嗅覚障害 1 例で あったが，ドライ・アイはみられなかった。術後出血は いずれも術後数日目に出現し，タンポンの挿入を要した。 そのため, 出血時の対応の困難な小児には本法は施行し ていない. 術後 6 力月成績は, 鼻汁に対して著効 $16 \%$ 有 効 $48 \%$, 鼻閉に対して著効 $8 \%$ 有効 $40 \%$ ，〈しゃ夕に対 


\section{して著効 $12 \%$ 有効 $8 \%$ であった.}

本法は従来の経上頱洞法ヴィディアン神経切断法に比 べ効果の点ではやや劣っているが, 手術侵襲と合併症が 少ない点で優れている．また他の治療法が無効であった 難治症例を対象としており，評価できる成績と考えられ る.

\section{参考文献}

1) 須藤直廣, 山下敏夫, 熊沢博文, 他 : 鼻アレルギーに対す るレーザーの使用経験. 耳鼻臨床 $76: 869 \sim 875,1983$.

2) Fukutake T, Yamashita T, Tomoda K, et al : Lasey surgery for allergic rhinitis. Arch Otoialyngol Head Neck Surg $112: 1280 \sim 1282,1986$.

3 ）友田幸一, 大西純夫, 待木健司: 鼻アレルギーに対するレー ザー治療の検討 一鼻粘膜血行動態を中心に一. 耳鼻臨床 $81: 221 \sim 227,1988$.
4 ）福武知重, 山下敏夫, 友田幸一, 他 : 鼻アレルギーに対す るレーザー手術. 耳鼻臨床 $81: 1163 \sim 1179,1988$.

5 ) Kawamura S, Fukutake T, Kubo N, et al. Subjective results of laser surgery for allergic rhinitis. Acta Otolaryngol (Stockh) Suppl $500: 109 \sim 111,1993$.

6 ）川村繁樹, 久保伸夫, 福武知重, 他 : 鼻アレルギーに対す るレーザー手術の検討 一第 1 報 : 効果の持続性の検討一. 耳鼻臨床 $86: 531 \sim 539,1993$.

7 ) 川村繁樹, 久保伸夫, 福武知重, 他 : 鼻アレルギーに対す るレーザー手術の検討一第 2 報 : 再手術の有効性の検討 一. 耳鼻臨床 $86: 681 \sim 686,1993$.

8 ）川村繁樹, 久保伸夫, 福武知重, 他 : 鼻アレルギーに対す るレーザー手術の検討 一第 3 報 : 効果発現機序の検討一. 耳鼻臨床 $86: 815 \sim 821,1993$.

9 ）増田成夫, 黄川田徹, 加藤洋治, 他 : 蝶口蓋孔鼻内焼灼法 による鼻アレルギーの治療について.日耳鼻 $97: 1817$ 1818, 1994 .

4. 鼻アレルギーに対するバルーンレーザーサーミア 一その基礎と臨床一

出口浩二

はじめに

温熱療法(ハイパーサーミア)は, 癌や泌尿器科領域の 前立腺肥大症の治療に応用されている. 耳鼻咽喉科領域 に执いても，フランス・パスッール研究所とイスラェル ・ワイスマン研究所の共同研究で鼻局所温熱エアロゾル 療法装置が開発されて以来, ウイルス感染による急性鼻 炎や鼻アレルギーに対する有用性が確認されている11. またこのエアロゾル療法に执いて， $32^{\circ} \mathrm{C}$ と $43^{\circ} \mathrm{C}$ の 設定温度に打ける臨床効果の差を確認し, 明らかに 43 ${ }^{\circ} \mathrm{C}$ での治療が有効であるとの報告もみられる2)。この ような経緯のなか，日本に扣ける耳鼻咽喉科外来診療の 中でも, このエアロゾル療法が広く行われるようになり つつある.

今回, 上記に加光，以下に述べる基礎データを根拠に， より確実に温熱効果を得る目的で,レーザーを用いた温 熱療法を行った.

\section{温熱療法前後の上顎洞内局所への エアロゾル蓄積の推移}

今回の治療に先駆けて, 鼻アレルギー単独ないし鼻ア レルギーを合併した慢性副鼻腔炎と慢性副鼻腔炎単独の 症例を対象に温熱療法の効果をみる実験を行った。

i ) 対象と方法

対象は鼻アレルギーを合併した慢性副鼻腔炎症例, あ るいは, 鼻アレルギー単独症例 5 例 (上顎洞10側) と慢性 副鼻腔炎症例 4 例 (上顩洞 8 側)において検討した. 各症 例は, 最初に 8 分間, $99 \mathrm{mTc}$-フィチン酸 $20 \mathrm{mq}$ でラベル した $10 \mathrm{ml}$ の注射用蒸留水で鼻ネブライザーを行い, そ の後, ガンマービュー(日立製作所製)を用い, 実際に吸 入した ${ }^{99 \mathrm{~m}} \mathrm{Tc}$-フィチン酸の量を 30 分間(20秒毎の 90 フ レーム)測定する. この後, スカイナー $($ エーザイ株式 会社）を用いて温熱療法を10分間施行した後, 同様に 8 分間の鼻ネブライザーを行い30分間測定した。な括，ネ 